\title{
Coastal Risk Management Modes: The Managed Realignment as a Risk Conception More Integrated
}

\author{
Hugues Heurtefeux, Paul Sauboua, \\ Provence Lanzellotti and Amandine Bichot \\ EID Méditerranée, Montpellier,
}

France

\section{Introduction}

Land managers assess the risk by evaluating the probability of hazard occurring and likely damage that would occur to economic assets. There are two types of hazards. The first is caused by wave action, near-shore current and wind effects; which imply erosion and its associated risk of flooding. The second is increased by physical structures that have been built with the aim of protecting the coastline. Storms can induce the destruction of coastal protections as dunes and promote the sea submersion. Sea submersion is a temporary flood of coastal area due to the sea and needing extreme weather conditions. Given the importance of biodiversity and attractive nature of coastal areas, they present different stakes. There are socio-economic stakes as people, amenities, activities and infrastructures. And in the same way, there are natural stakes and cultural heritages as natural areas and historic building.

To anticipate coastal risks, coastal management has always been a major question for land managers. During the XIX ${ }^{\text {th }}$ century, Victor Hugo himself has made speeches to outline the vulnerability of coastal areas to these hazards (Hugo, 1846). For a long time, hard structures were built to hold the line and to provide high level of protection to population. These options more easy to develop were usually used because of absence of knowledge. But in the last twenty years, new approaches to manage coast have been developed.

This shift of coastal management by the decision makers has depended on the appearance of the Integrated Coastal Zone Management (ICZM) concept too. The ICZM is originating from the US and adapted in France via Europe. It replaces a protectionist policy, long based on a naturalistic approach. Taking consideration of the economic, sociological, biological concerns and the democratic, educational and political ones as well, with in addition the relationships between the various partners involved, is a land management way that cannot be ignored these days of sustainable development (Bawedin, 2009).

One of these new approaches to manage coastal areas corresponds to the managed realignment (MR). Different cases of managed realignment exist and constitute a heterogeneous set. Indeed local context differences as the type and the importance of stakes and hazards, of sites topography, but especially of coastal management conceptions into public policies, induce an important diversity of M.R. cases. Thus in a context of thoughts 
about management modes to use into coastal areas, it seems necessary to analyse this emerging notion. This publication will permit to study in a first part (i) the M.R. notion, and the objectives and actions to which they correspond to. Overviews in a second part will permit to evaluate in France (ii) a case where MR seems to be a pertinent option and an other (iii) where MR option has been set up.

\section{Emergence of a coast management mode, the managed realignment (M.R.)}

Land managers have always tried to limit the risks resulting to the interaction between present coastal stakes as population, housing and infrastructures presence, with coastal hazards. This objective has sometimes implicated the obligation to shift some of these stakes because of the evolution of extreme events in their intensity or frequency. Some old marginal cases existed like the Brighton Beach Hotel at Coney Island (New York, United States) which has been shifted during the XIXth century of about 180 meters because of storm wave action (Trevi, 2008). But the majority of M.R. cases are quite recent. The reality proved than for a long time hard structures like seawalls, embankments, groynes, breakwaters were built to hold the line and to provide high level of protection to population. These options more easy to develop were usually used because of absence of knowledge (no strong computers for efficient numerical models, no climate change context) and cultural attitude (coastal lands loss was difficult to accept, whereas dykes increase safety sentiment). In the last twenty years, four global approaches to manage coast have been developed (cf. figure 1):

- The approach by holding the line, as presented above, has persisted to be used. Traditionally, the goal is to protect developed area using hard structures (Klein and al., 2001).

- The "do the minimum" approach. It corresponds to the use of natural processes to reduce risks but permitting coast natural changes. Some of the techniques used with this approach attempt to limit rather than to stop coastal erosion and cliff's retreat;

- The "do nothing" approach, which is rare but can be found. One of the more famous cases of "do nothing" approach is the municipality of Happisburg, in the county of North Norfolk (UK). The storm waves reached the coast with important damages on the bottom of the cliff, the cliff fell with mayor impact on the houses totally destroyed (cf. figure 2). Do nothing is one of policies adopted when it's too late, when any decision has been thought before, when the cost benefit analysis shows than the defence front to the sea exceeds the value of the properties.

- The M.R. approach which is quite recent. Its definitions and its particularities will be presented below.

Climate change would tend to modify coastal hazards. Thus as the $4^{\text {th }}$ evaluation report of the Intergovernmental Panel on Climate Change (IPCC), means sea level will have for the 2090-2099 decade a rise inclusive between 0,18 and 0,59 $\mathrm{m}$ in comparison to the 1980-1999 period (IPCC, 2007). In the same way, as the report of the National Observatory on Climate Change effects, Climate change is happening with several effects directly observed on the coast (ONERC, 2007) :

- Sea level rise,

- Growing of damage by river and sea floods on the coast,

- Trend of more storms but not totally confirmed. 


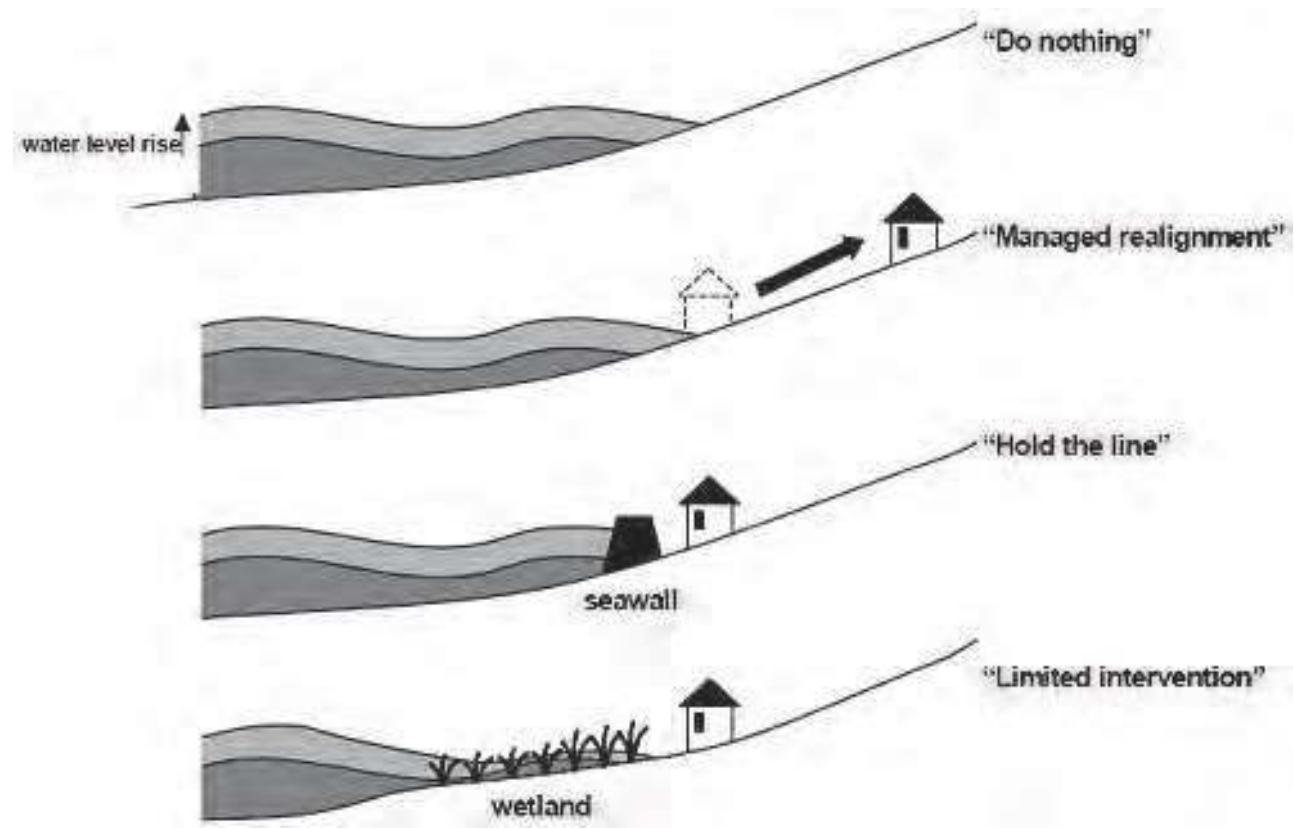

Fig. 1. Policy options for coastal management (European Commission, 2004)

This coastal evolution has an impact on coastal management. In the recent past; land managers were using a different approach in which properties were not moved but instead, protected by hard structures. The use of this holding the line approach has started to be criticized. It has some economic drawbacks (high construction and maintenance costs), environmental drawbacks (breaking of the natural dynamic of the longshore current into the sea sediment cell) and spoils the landscape. Moreover this management mode can be especially questionable into the reasoning. The focus is on the problem of sediment flows rather than on their causes (EID-med, 2010).

An analysis of advantages and disadvantages of the classical management approaches and the evolution of natural hazards have led to a reassessment of these conventional management methods. Thus due to this reassessment, managed realignment projects have been implemented quite recently. One of the oldest (1987) realignments in Europe is Beltringharder Koog, state of Schleswig Holstein, Germany. To compensate for the adverse effects caused by a new polder (land reclamation) built in the Nordstrand Bay, a salt water lagoon and an intertidal habitat were created with a surface area about 1000 ha (ABPmer). M.R. needs political support to make the public aware of the benefits of this approach. That's why this concept has for a long time been difficult to implement

\subsection{Different coastal areas management policies represented by a set of definitions}

For a long time managed realignment used to be called managed retreat. That was the case in England for example. This term has gone out of favour, since it implies negativity in coastal management, and a "retreat in the face of the enemy", rather than a rational management choice (Rupp and Nicholls, 2002). For the British Government, the M.R. of coasts and rivers is defined as a process of establishing a new flood defence line for river 
corridors or coastlines often set back from the existing position, with the aim of improving the long-term sustainability of the defence, or contributing to other aims such as habitat creation (DEFRA, 2005). For Laure Ledoux (Ledoux, 2005), this definition must be understood as the definition of a new defence line, on the coast line but into the estuaries and bank rivers too. So it is in question of a voluntary approach and pro-active, in opposition to "inactive realignment" limited to not look after existing defences. M.R. objectives are numerous. It permits so a diminution of defences costs by the reduction of structures dimensions, and the increase of defences effectiveness and durability due to wave's energy absorbed by the wetlands created. There is an ecosystems creation or restoration too, with sometimes for specific objective to satisfy biodiversity protection criterions as defined by European directive on habitats. Another objective, in the particular case of estuaries, can be the obtaining of a more stable form face to the sea level rise, or to have an influence on sea level and flood risk.

M.R. consists generally in the artificial creation of a breach in existing structures (Dickie, 2010) (cf. figure 3). It permits to water to flood until the next natural relief or the new defence line constructed more into the hinterland. In this case, M.R. is more corresponding to a process of depolderisation. Indeed Western Europe's depolderisation was launched in the 1980's. A lot of different cases exist in United Kingdom where precisely management policies are directed towards M.R. (Goeldner-Gianella, 2007).
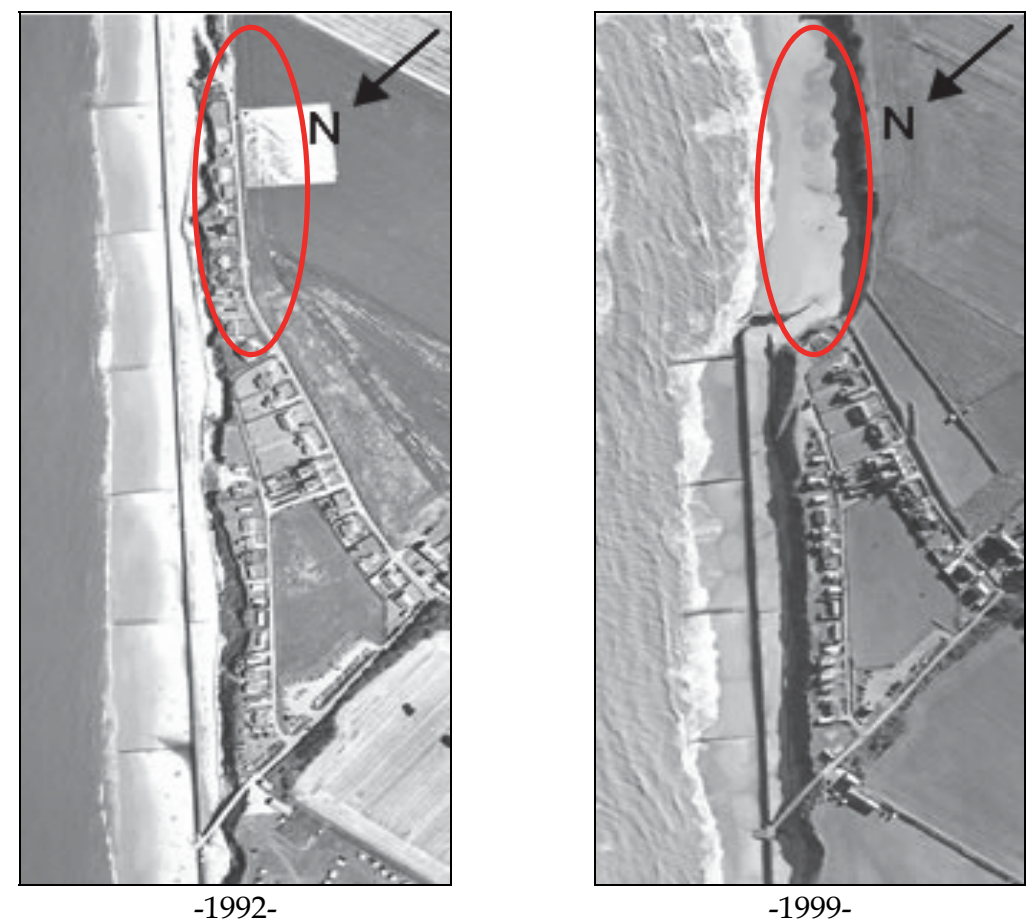

Fig. 2. Case of "do nothing" approach in Happisburgh (UK) (Coastal Concern Action Group) 


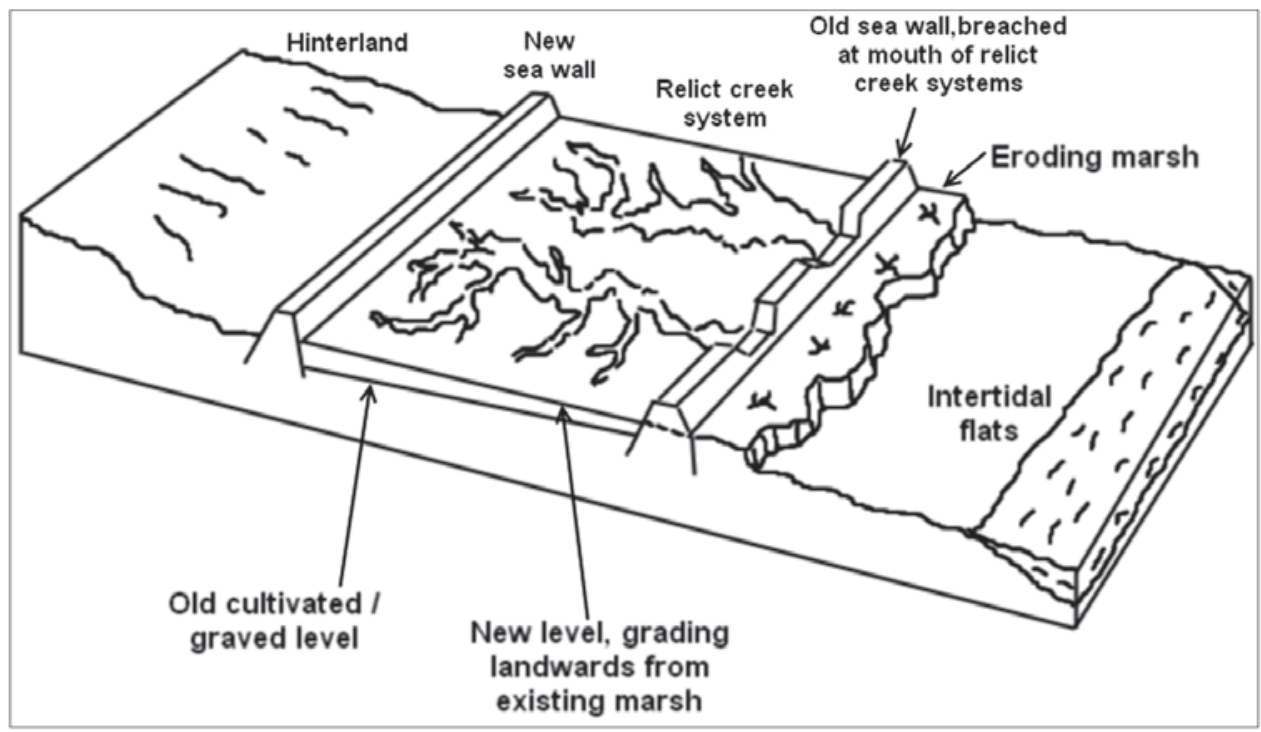

Fig. 3. Representation of strategic realignment (Rupp and Nicholls, 2002)

Since 2005 the management of risks in United Kingdom is concerned by a new strategy called "Making space for water". The main goal of this strategy is to consider environmental and social aspects of floods and coastal protection. It will put forward adaptation recommendations to climate change and promote managed realignment. This strategy includes the recognition of socio-economic, tourist and environmental factors in their totality, the improvement of knowledge relative to hazards, cooperation between stakeholders, development of innovative solutions and the consideration of these risks into land management plans. The same consideration of social, economic and environmental aspects is taken into account in area of flood management in Belgium. In that way, Belgium is a partner with United Kingdom of the project European Spatial Planning: Adapting to Climate Events.

Managed realignment is used in United States too. It is defined in the same way as in United Kingdom but it implies the abandon, the destruction, or the construction shifting on sectors potentially liable to flooding (SFP and URA). In United States, managed realignment is favoured by goods relocation aid and buy-back programs. These programs can be used to promote managed realignment and avoid complaints from sectors where an unconstructible area has been defined. With this coastal management approach, indemnification and relocation possibilities are taken into account.

In France, it is underlined that the process of realignment consists in a switch as a straight line. Thus there is a disappearance of uncertainties areas that make the richness of coastal environments (Léger, 2005). So the term of hindsight is more used in France. It is defined as a backward step or movement. This distant position into the space or into the time permits a better vision and assessment. Hindsight management objective is rather to move back present stakes on the coast towards the hinterland. That corresponds to an integrated management policy. 
Another type of term is used. In Canada retreat is more used to define the shunning of the risk: retreat or shunning consists in avoiding risks so as to eliminate direct impacts. Instead of attempt to protect land against sea encroachment, we give up to development project and we choose rather to abandon threatened land when conditions become intolerable. For example, it is possible to resort to a dissuasive regulation to reduce losses due to erosion. In some cases, restoration can be an alternative solution profitable for coastal constructions. Retreat corresponds to a proactive adaptation form to eliminate a direct impact. Easier retreat form consists in avoiding to buy vulnerable estates, in the case of individual buyers, or to construct in areas with a flood or erosion risk (Canadian Government, 2004).

By this process, the objective is rather to avoid the creation of new coastal stakes than to remove already existing ones. Finally coast line will be abandoned especially if natural hazards are strong but it is not a shifting policy strictly speaking.

The analysis of the different used terms indicates that these differences could be explained in a first part by a difference between expected objectives. These objectives would be to move back the stakes present on the coast to the hinterland, to create a new defence line backwards facing the sea to restore natural areas and a buffer space between sea and stakes, and to avoid the addition of new stakes at existing ones into coastal areas (cf. figure 4). It appears in a second part that these terms aren't used in the same countries. It could be the expression of the existing heterogeneity between countries with coastal line about their strategic orientations of coastal management.

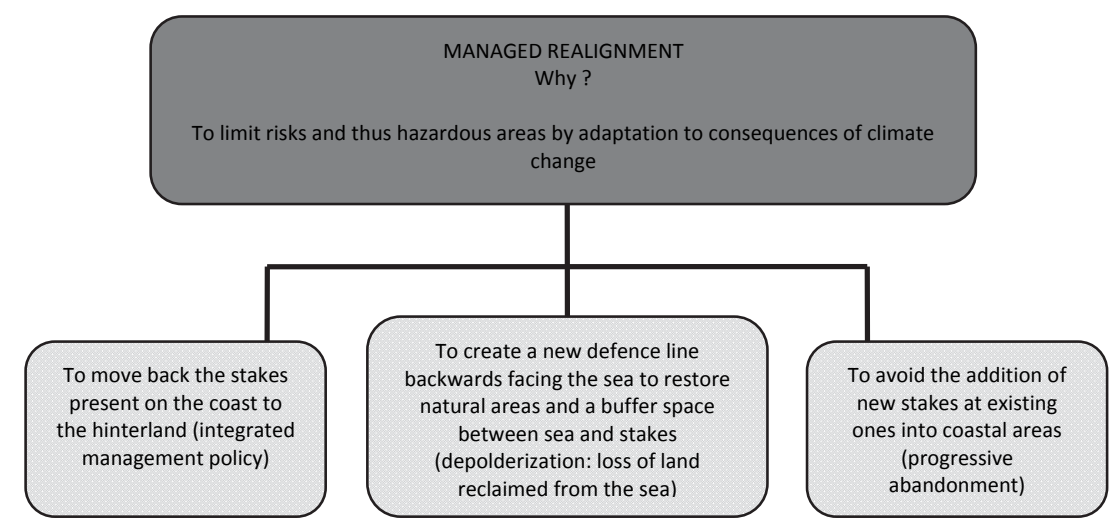

Fig. 4. Strategies diversity linked to managed realignment

\subsection{Overviewes of managed realignement use in the french context \\ 1.2.1 To the European scale}

Managed realignment is discussed by European Commission in order to respond to increasing coastal risks and climate change (European Commission, 2007). Coastal development and management have to be tackle in a strategic, coherent and integrated way. A guide about European Union action in view of climate change has been published in 2008 (European Commission, 2008). Nevertheless these recommendations are more based on the struggle of climate change than on the thorough adaptations. Erosion and marine submersion are analysed only with an economic and speed of execution points of view. Thus M.R. isn't really promoted into this report. 
To present more especially coastal zones, General Direction for Environment has set up the Eurosion program in 2004. The objective was to assess the needs of action in view of erosion at the European Union, the states and region communities scales (European Commission, 2004). According to this program, to European scale, from 1999 to 2002, because of shoreline erosion between 250 and 300 landowners had to leave their house. Four recommendations result from this report:

- To strengthen coastal resistance by the sediment balance restoration

- To take into account coastal erosion coasts in development and investment decisions

- To think ahead at coastal erosion and to plan solutions

- To consolidate knowledge basis concerning management and forward planning of coastal erosion.

M.R. is described as a method to struggle with coastal erosion. To leave risked areas to install stakes into the hinterland is presented as a safe solution in an environmental and economical point of view. Nevertheless only a few case studies of Eurosion program are describing this technique. It is limited and concerns only the areas with limited stakes.

\subsubsection{To the national scale}

In France, development principles of coastal areas used before present some limits into the current context of sea level rise and sediment deficit. Into the most vulnerable sectors, maintain artificially coast line isn't viable in an economic and ecological point of view. The National Observatory on Climate Change Effects (ONERC) has recently reminded the importance of sharing locally the coastal risk culture, especially to set up managed realignment project (ONERC, 2007). Among recommendation made by the ONERC, it is stipulated that M.R., already practised in United Kingdom and in few Conservatoire du littoral's properties, needs to be carefully studied and planned in relation to predictable climate change consequences on the coasts (coastal salt-affected land, coastal erosion, submersion of low coasts, etc.). Moreover M.R. needs to be integrated into the regulatory context to be more efficient. It seems necessary to draw on Risks Prevention Plans, when they exist. It is possible to use existing rules, as the Coastal Law, which should be more implemented, or even strengthened. Communication on climate change can help local authorities to take public interest servitude into account in their choices of coastal strip development or urbanization.

The ONERC considers too that information exchange at an international level about managed realignment is necessary. Thus it is advised to participate at networks such as the European marine outlying regions debate, permitting to capitalize on foreign experiences.

In France M.R. projects are not numerous. Coastal areas managers just begin to set up this type of management method, that is why it is pertinent to analyse the decisive factors and objectives of two of them.

\section{The case of petite camargue : the pertinence of the managed realignment option}

\subsection{Presentation of the PETITE CAMARGUE site}

The Espiguette is an area where a vast dune system spread, unique case in LanguedocRoussillon. Between the Espiguette sandy spit and the Rhône Vif (cf. figure 5), the site orientation is North/South then North-West/South-East and finally West/East: many different attack angles for the local marine winds. The downdrift, oriented from East to 
West, is estimated at more than $200000 \mathrm{~m}^{3}$ of sand per year, which represents one of the most important in Languedoc-Roussillon.

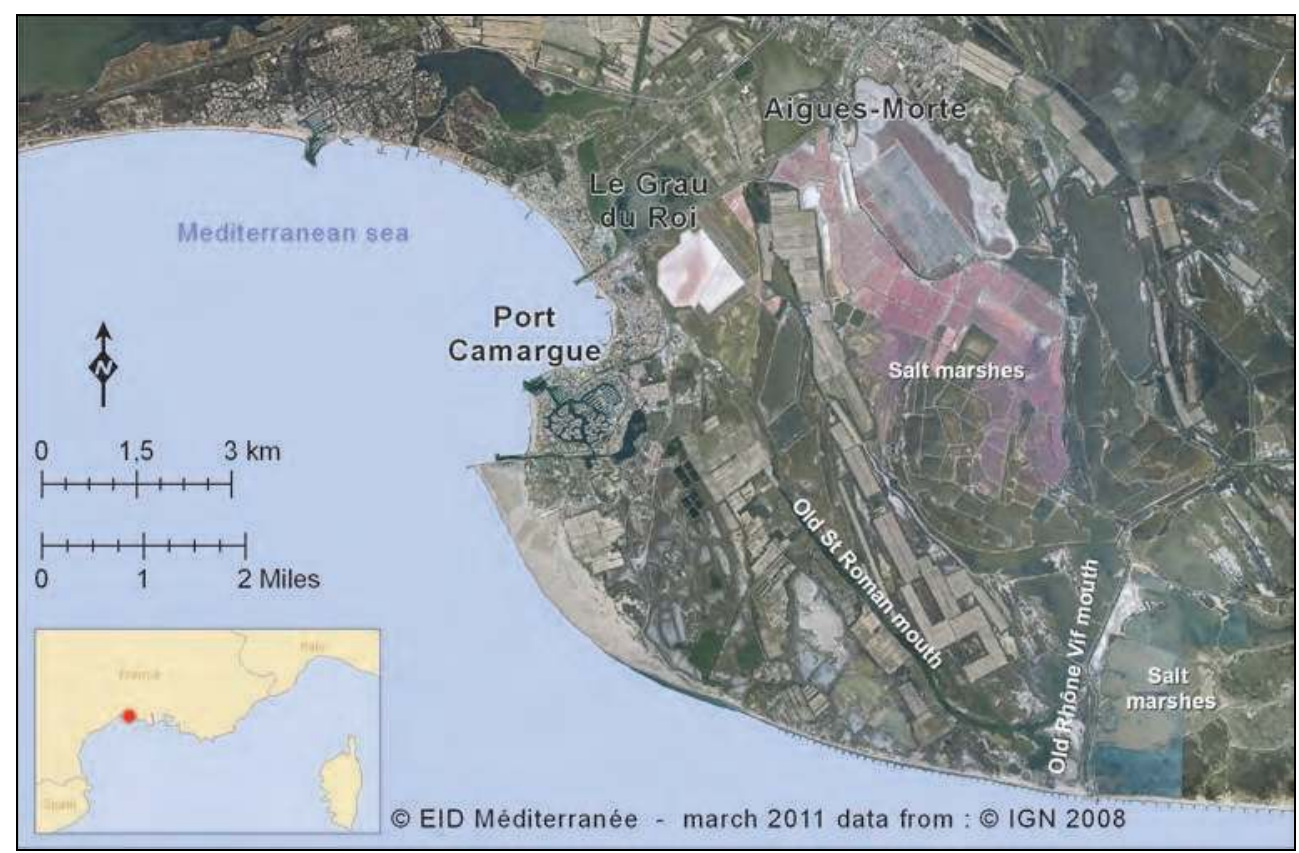

Fig. 5. Espiguette coastal dune slacks location

From the hinterland to the sea, there are dune massifs which the older is alongside the St Roman's Rhône (cf. figure 6). The last-mentioned has been flattened and cultivated, reducing the altimetry ratings and thus weakening the area natural protection. Another production has been developed too. Petite Camargue lagoons have been converted and divided for salt production by the Salins du Midi Company. The old Rhône Vif opening on sea has been equipped with waterworks and provides the whole of Aigues-Mortes salt marshes today (CELRL, 1998).

On this sector, the shore didn't stop to evolve. The main problem is the submersion risk following dune slack rupture during storm events, threatened the commune of Grau-du-Roi (as November 1982) and its sea opening Port Camargue. These coastal facilities have been built at the end of 60 's, at the Espiguette spit extremity, within the sandy strip.

The overall anthropogenic perturbations have produced many disturbances leading the classical arsenal of protection methods setting up, in a period (1960-1980) when "coastal management didn't leave space to technical doubt" (Moulis, 2006). The first works, beachbed rip-raps and groynes, have been realised on Eastern Rhône Vif. There have been set up in 1961 in order to ensure economic stakes protection of salt marshes. On Western Rhône Vif, some groynes of a hundred meters long have been installed in 1963 so as to protect the salt marshes water supply point. Then, they have been expanded further on West until 1997. Finally, it ends up with 46 groynes all $120 \mathrm{~m}$ on 5,5 km long. 
Later, at the end of 1990 to 2000, "dunes came to be opposed to rip raps" (Moulis, 2006) and the dune reconstruction has been preferred. Thus considering the extent of shore line retreat, this protection way by hard structures don't enable to struggle durably against erosion and submersion hazards. This complex and still wild territory permits to address coastal protection notion under a new overview, which makes it reasonable to think that the embankment and hard structures aren't systematic resorts.

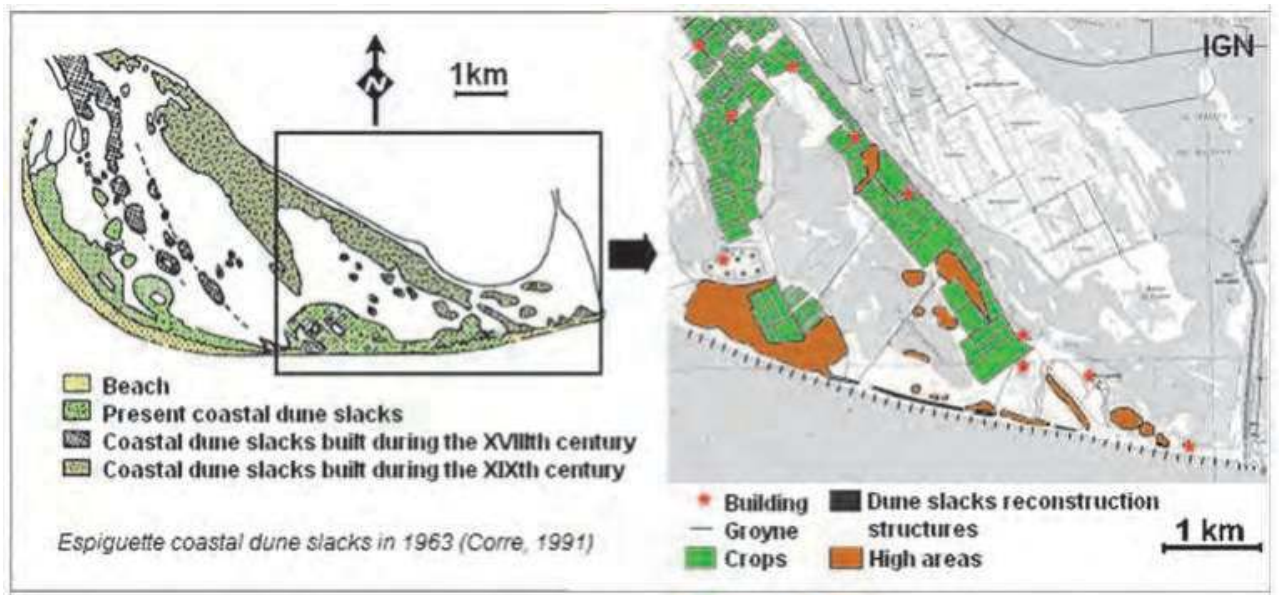

Fig. 6. Coastal dune slacks location and land use

\subsection{Camargue stakes: Economic and heritage interests \\ 2.2.1 Economic and tourist interests}

Espiguette presents several stakes. There are economical stakes, as the agricultural productions: asparagus production, vineyard and salt marshes, and the tourist activities for commune of Grau-du-Roi. Sea encroachments in relation with coastal erosion and sea-level rise constitute a threat for the economic activities. Indeed during high storms, the sea can invade hinterlands (IARE, 1994).

For salt producers, those submersions can cause the loose of harvest of a year, or even to reconsider the next year production. Since the beginning of the 60 's, salt producers have protected their entire coastline with a frontal sea wall and groynes. But the cost of these protection constraints has an influence directly on the price of a ton of salt. It implies consequences on sector profitability too. It's a real handicap in a world competitive market. Nevertheless, salt makers continue to protect their activity against sea encroachments.

In the same way, during exceptional storms, such as in 1982 and 1997, Port Camargue and Grau-du-Roi could be flooded by sea encroachments, coming from slack break. Damages are significant in those urban areas.

Regarding tourism, Espiguette beach knows a relatively moderate daily frequentation. There are 10000 peoples a day, in summer period, for a beach of 11 kilometres-long. Tourism facilities are not really developed. There are only four beach manager installations. However, regarding its wilderness, its environmental quality and its atypical morphology in Languedoc Roussillon, it's one of the most famous and appreciated beaches by peoples who are searching space and nature. 


\subsubsection{Heritage interests}

Espiguette dune slakes are the most conserved and the most spectacular of LanguedocRoussillon. They result from a particular dynamic due to the site situation compared with main winds. Therefore, this site is classed as "landscape title" and the Conservatoire du Littoral (Coastal Conservatory) has acquired 715 hectares here. Moreover this site presents protection areas too, because of Fauna and Flora inventory. It is a stopover for avifauna migratory, and the Petite Camargue coast has a mosaic of priority and community interest habitats in the European directive "Habitats". Furthermore, wooded dunes with Pinus pinea are the only one on the coast. Thus this sector conservation requires mainly a tourist frequenting management.

The Espiguette represents a wealthy succession of natural habitats. Those environments are fragile and sensitive to anthropogenic high pressures. However, their natural evolution and their maintaining require moderate natural disturbances by sea, wind and salt effects.

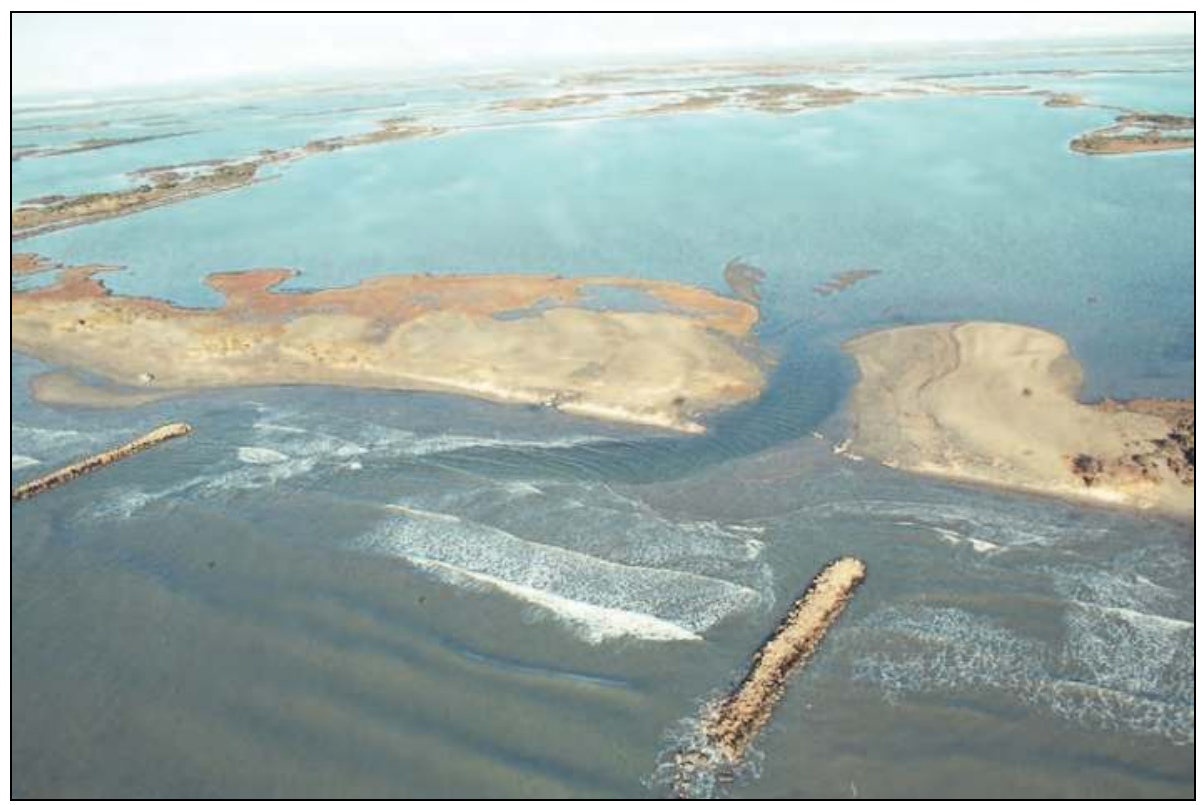

Fig. 7. Sea intrusion due to storm in 1997 (source : EID Méditerranée)

\subsection{From conservation logic to the reflection evolution: a point about conceivable solutions}

\subsubsection{The conservation logic from the 60's to the 90's}

The conservation of the most eroded coastal portion was providing to be necessary to protect salt marshes and avoid farmlands flooding. Started in the 60's, groynes and a frontal seawall setting up had quickly engendered the Grau-du-Roi coast erosion (cf. figure 8). The commune is located downstream from downdrift, immediately on West. So, this sector had been protected with groynes too.

Those settings up allowed to decrease the phenomenon in the set up area, but the erosion had been moved away to the West, by longitudinal sandy transit break off. So, the groynes 
presence just moves away the problem and their local protection role is even illusory, as the marine submersion risk in the back dune is still possible (Heurtefeux and Richard, 2005). Moreover, nowadays the shoreline have a 2 meters a year retreat (Sabatier, 2001).

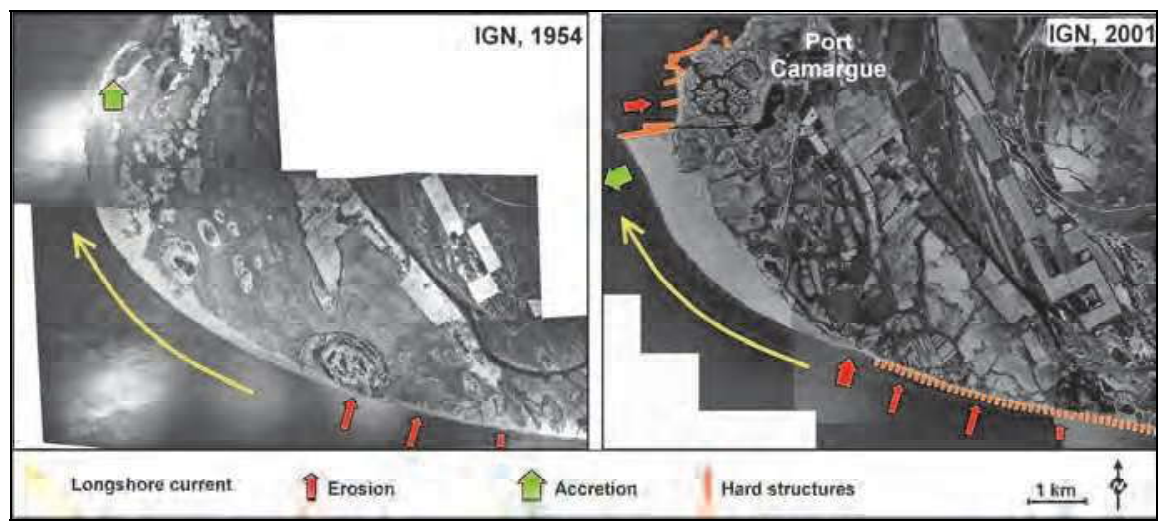

Fig. 8. Coast line evolution from 1954 to 2001

Today, it clearly appears that, on this sector, those kinds of defences do not resolve the erosion hazard and even move it away downstream from downdrift. Its global cost is high with a maintenance cost which is higher than the origin investment.

Therefore, today it's necessary to adapt the action at a local point of view and stop persevering to keep the shoreline, accepting the environment natural evolution.

\subsubsection{Policies and mentalities evolution}

Scientists have early taken the measure of the phenomenon complexity and understood that fight against Nature is illusory. But it is only in the $90^{\prime}$ s that all the technicians subscribed to this point of view.

In those days, related to the Integrated Coastal Zone Management, on this study site, there are only two possibilities: the "do nothing" approach, or realize a managed realignment. The analysis of different coastal management guidelines (EUROSION, for the European scale, CIADT for the national scale, and Strategic directions for the coastal erosion management in Languedoc-Roussillon for the regional scale) demonstrates that it would exist a consensus on hard structures use. It is advised in all these guidelines to reserve heavy structures (groynes, break-waters...) only for areas which including strong and not moving assets.

Thus in an area like Espiguette, erosion management has to be adapted related to the natural characteristics of this site. Others techniques, as beach nourishments, and dune slakes restoration should be promoted.

\subsubsection{Envisaged solutions}

This logic leads to distinguish between two risks which, even if they are related, lead to different responses:

- Erosion, which suppress a part of the stakes because of beach and dunes destruction : this action is irreversible and spatially limited 
- Submersion, that can hit very important expanses but limited in time. It leads to damages which not necessary cast doubt on area use.

In Grau-du-Roi, the erosion will not really destroy uses. Indeed, the most affected one is the seaside activity, but it can easily re-spread on the area in accretion near the Espiguette seawall. In commune of Saintes Maries, erosion causes more problems for the salt producers because it threatens the salt concentration system.

But in another way, submersion threatens important stakes on Grau-du-Roi sector. Economical stakes as tourist activities and salt marshes could be damaged and environmental ones too such as nature sanctuaries.

Realised analyses demonstrate that the mean risk on Grau-du-Roi territory is submersion, not shoreline retreat. So, it permits to foresee to process differently for the two hazards. For the protections against submersion, the main principle consists to raise roads and trails which surround urban area. As complement, hydraulic works setting up on irrigation canals allow to protect crops and to facilitate soils re-drying up. Regarding erosion management, the objective is not as today: fix the shoreline at any cost. But it evolves toward the restoration of a balance or even toward an acceptable managed realignment. This option depends on its compatibility with salt producers activity. On the long term, heavy structures as groynes are very onerous and that defence cost can exceed the value of assets to protect. An interesting option could consist in rehabilitation in several steps:

- Firstly, the construction of a second line dune on the old slakes built in the 18th century. In the same time, the border dune maintenance could be reduced.

- Secondly, when the back dune will be strengthened, the border dune management could be stopped.

The protective dune location on the old dune slakes disturb not much area functioning, because they have been levelled before (Corre, 1984). Their reconstruction consists more in a habitat restoration than in transformation. Moreover, on old dune slakes level, sand transports are limited and topography stay stable (Corre, 1971) so that makes vegetalisation easier.

Furthemore, the progressive reduction of border dune maintenance could be beneficial for embryonic dunes habitat development. This habitat is not much abundant at the East site because of erosion features observed on the area and the beach-shifting dune direct transition. They are mainly present in openings of shifting dune caused by sea submersion (Favennec and Larroque, 2004). Allow seawater penetrate in a controlled buffer area permits to maintain vegetal communities dynamic dependent on seawater inputs and to protect human stakes situated more in the back.

The ecological stake on Espiguette site is important and it's necessary to find a compromise between important seawater intrusions and a lack of water. Those perturbations maintenance is particularly fundamental for the salty steppe habitat, because seawater intrusions permit the conservation of a low vegetal covering, favourable to the development of rare and protected pioneer species present in this habitat (Favennec and Larroque, 2004). However, fresh water presence in areas protected by dune slake is essential for the maintenance of this site's flora biodiversity (CELRL, 1998). The protection of juniper trees and Pinus pinea priority habitat, sensitive to too high sea influences, pass by controlled sea intrusions.

Nevertheless the sea level rise will prolong backwards, the salty corner influence. In certain depression area, if ground salinity rises, we could find a development of halophilic thickets, non priority habitat but not much present on this site. They have a big value for the 
avifauna, as nesting site and migratory stop (CELRL, 1998). In this context too, the ground salinity increase will more justify dune slake in back to limit increase of salinization.

All these propositions are aimed to avoid heavy structures to respect dune-beach system and its intrinsic transfers in order to not damage ecosystem functionalities. It's necessary to consider dune-beach system in its totality, and thus its natural capacity to return at an initial state after a perturbation. Beach nourishments in the most eroded area, using sand stock along Espiguette's seawall should complete usefully that system.

Today, it's really important to be conscious that the major risk for Grau-du-Roi is the sea submersion. To limit this hazard, concerning the financial and technical points of view it is unrealistic to hope fixing the shoreline and stabilizing dune slack. So, two actions must be realised in the same time:

- A "terrestrial" management of sea submersion by a precise protection of the stakes

- An erosion management with methods adapted to natural characteristic of the study site.

\subsection{Territory complexity, a real palimpsest \\ 2.4.1 A particular territory: The Camargue}

Today, in Camargue, flooding risk or erosion management takes place in a relatively rigid context, inherited from the past, in response at this socio-hydraulic system setting up history (Allard and al., 2005). In 1859, national policies have induced the achievement of frontal seawall closing and the protection of Camargue from seawater intrusions. Those protection systems gave to people from Camargue an impression of absolute protection and the economics activities have prospered (Allard and al., 2005).

Even after the huge floodings in 1993, 1994 and 2002; for certain inhabitants, the recognition of Camargue as potentially liable to flooding territory is not today always an evidence (Allard and al., 2005). The evolution of risk and the limit between acceptable risk and unacceptable risk is above all explained by "the risk perception that has population according to their culture, belief, in their security searches" (Allard and al., 2005).

Believing to control flooding risk, human societies have contributed to increase their vulnerability. Today, a new policy of management emerges, resulting from realization that the natural risk cannot be controlled in its totality: "People can't do anything against Nature. They can protect themselves but not control it" (Allard and al., 2005). However, human can sometimes help Nature or use it, which is the ecological engineering. Thus it is necessary to share lessons resulting from mistakes done in the past about coastal protection and to inform by these experiences decision-makers.

If we want to be optimistic, we could consider that population of Camargue had for a long time learned to live with Rhône fluctuations and sea water intrusions.

The economic restructurings are linked to dynamic instability, and in Bernard Picon's opinion "it is quite vain to wonder about environment and humans' aptitude to change, because adaptation acknowledgement is evident" (Picon, in Bethemont, 2000). But, we may also think that the population, struggling for a long time with those hazards, should not support a return at a previous state: the fear of money loss seems to hide more than an identity loss. The Camargue is a space oriented to change: in a century, farming evolved from a dominance of wheat and sheep to a wine dominance then rice production, to ends currently with a sharing of all those activities (Bethemont, 2000). Today, it's needed to know what it's better to promote for Camargue's inhabitants: tourism or farming activities. 


\subsubsection{A technical and administrative complexity}

The Rhône's delta system has not to be studied only on its seafront. It has to be studied on its entirety, taking into consideration the river-coast interactions. Thus the suggested managements must permit the flood water discharge from rivers too.

In addition, the administrative muddle doesn't make easier the setting up of joint representations. The site is on two different departments the Gard and the Bouches du Rhône, which are French territorial divisions, and it depends on two different communes: Le Grau-du-Roi and Les Saintes Marie de la mer. Moreover there are two different managers of natural areas which are the Camargue Gardoise Association and the Camargue Regional Park.

The number of stakeholders in this case is more important than for a classic case. That is the reason why it is really necessary to define clearly and globally what stakeholders want to protect and what kind of means they are able to do. Communication, between managers, technicians and users is essential in that kind of project with many stakes.

\section{The case of sete sand strip: an example of managed realignement project}

\subsection{Presentation of the Sète-Marseillan sand strip's site}

The sand strip between Sète and Marseillan is a littoral sand line of 11 kilometres long and 1 to 2 kilometres wide, with a dune. It separates Thau lagoon to the Mediterranean sea (cf. figure 9).

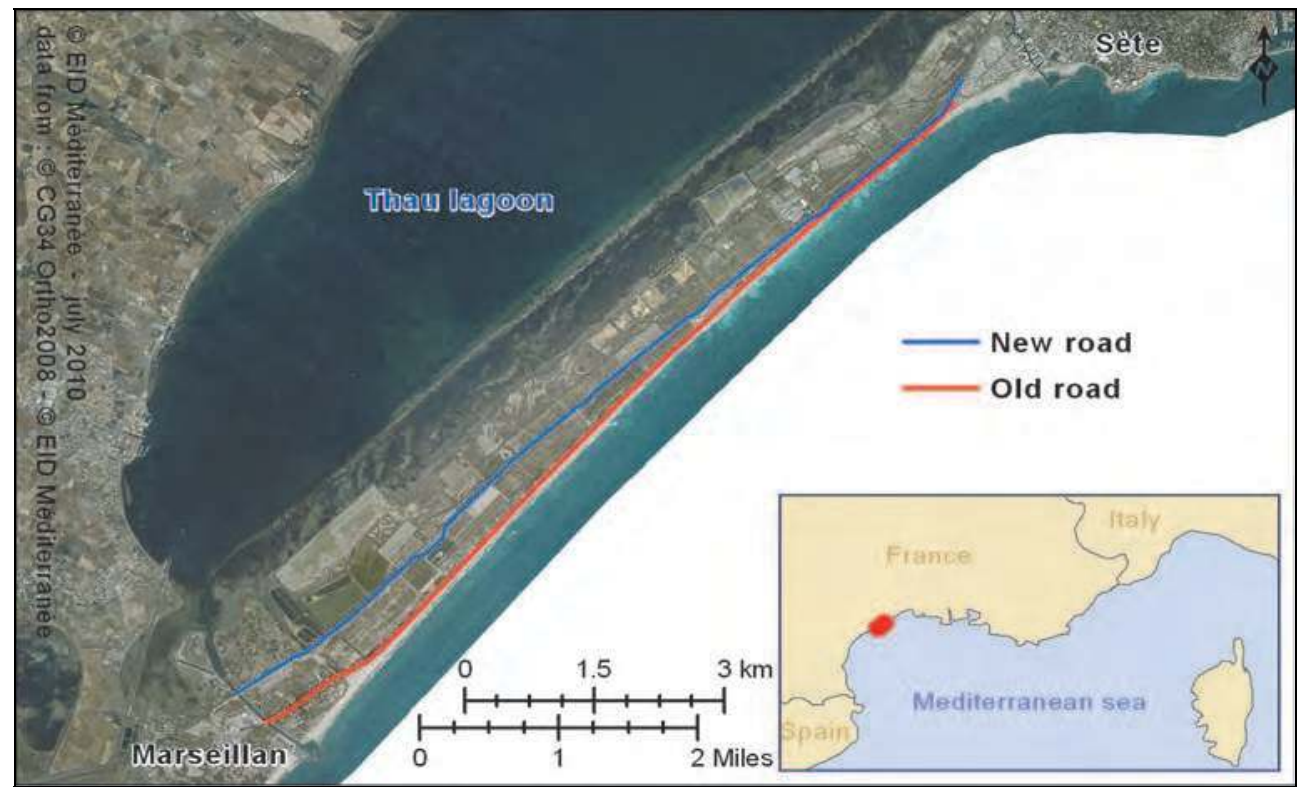

Fig. 9. Sète-Marseillan sand strip

As presented in figure 10, this space presents a lot of different economical stakes. There are a bottle-filling firm which is the main economic actor (120 employees), a four stars camping with 1000 places and two high traffic communication axis: a railroad and a road. 
Furthermore the sand strip's beach corresponds to a real economical stake with the influx of tourists. Its frequenting of tourists is up to 1000000 per year (Thau Agglomération, 2009). The economical stake of the influx of tourists depends also on bars and restaurants located on the beach. For comparison on a smaller beach located at 30 kilometres on the west, the 14 bars and restaurants generate a turnover of 15.2 millions of Euros per year (CCI Montpellier, 2010).

This space comprises a patrimonial stake too, the world conservatory of vine genetic resources with a collection of 7500 plants representing 2250 different grape varieties. Moreover this space presents a high ecological interest, in particular on lagoon's side with the lagoon and wetlands.

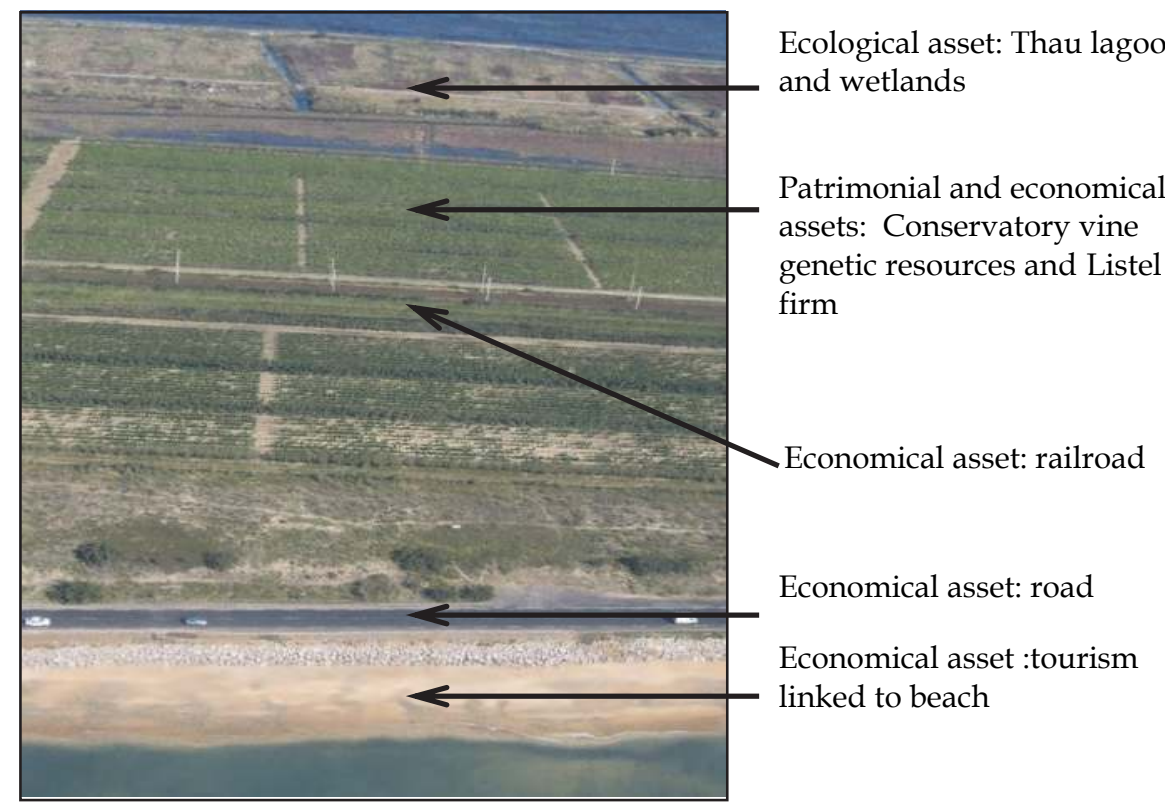

Fig. 10. Assets on Sète-Marseillan lido

But this space is threatened by storm wave action. Thus between 1937 and 1999 the sand strip has been subjected to a slow erosion, in particular at its two edges where observed recessions are longer than 50 meters (Durand, 1999) (cf. figure 11). Since 1954, the sand strip has lost 45 hectares. Nevertheless the threat is not particularly on the mean erosion rhythm, but on the modalities of this erosion. It doesn't exist any wide inter-tidal area in South of France because of microtidal system. Sète-Marseillan sand strip is really more vulnerable during storms, that is to say just a few days, than to the long-term observed evolution. For example, during the four days storm in 1997, with a fifty years period, shoreline recession has been longer than 30 meters in some spots.

Even if the morphology of the beach is reconstituted next a few months following these high erosion events, these high recessions set serious matters. They result notably in more and more frequent breaks of littoral road (cf. figure 12). 
The fragility of Sète-Marseillan sand strip is due to natural factors. The littoral depends directly on South/South-East sectors swells, oriented into the dial $90^{\circ}$ to $180^{\circ}$. These swells can have for expression extremely violent storms with maximum height up to six meters in extreme cases, and with important sea surges up to 1 meter of French General Height. For information maximum astronomical tide isn't up of 0,35 meter of French General Height and the main wave statistics on this coast show that $80 \%$ of significant wave height (Hs) is less than $1 \mathrm{~m}$. In the beginning of 90's, in spite of beachbed rip-raps, the coastal road between Sète and Marseillan was regularly subject to collapse, even by annual occurrence events.

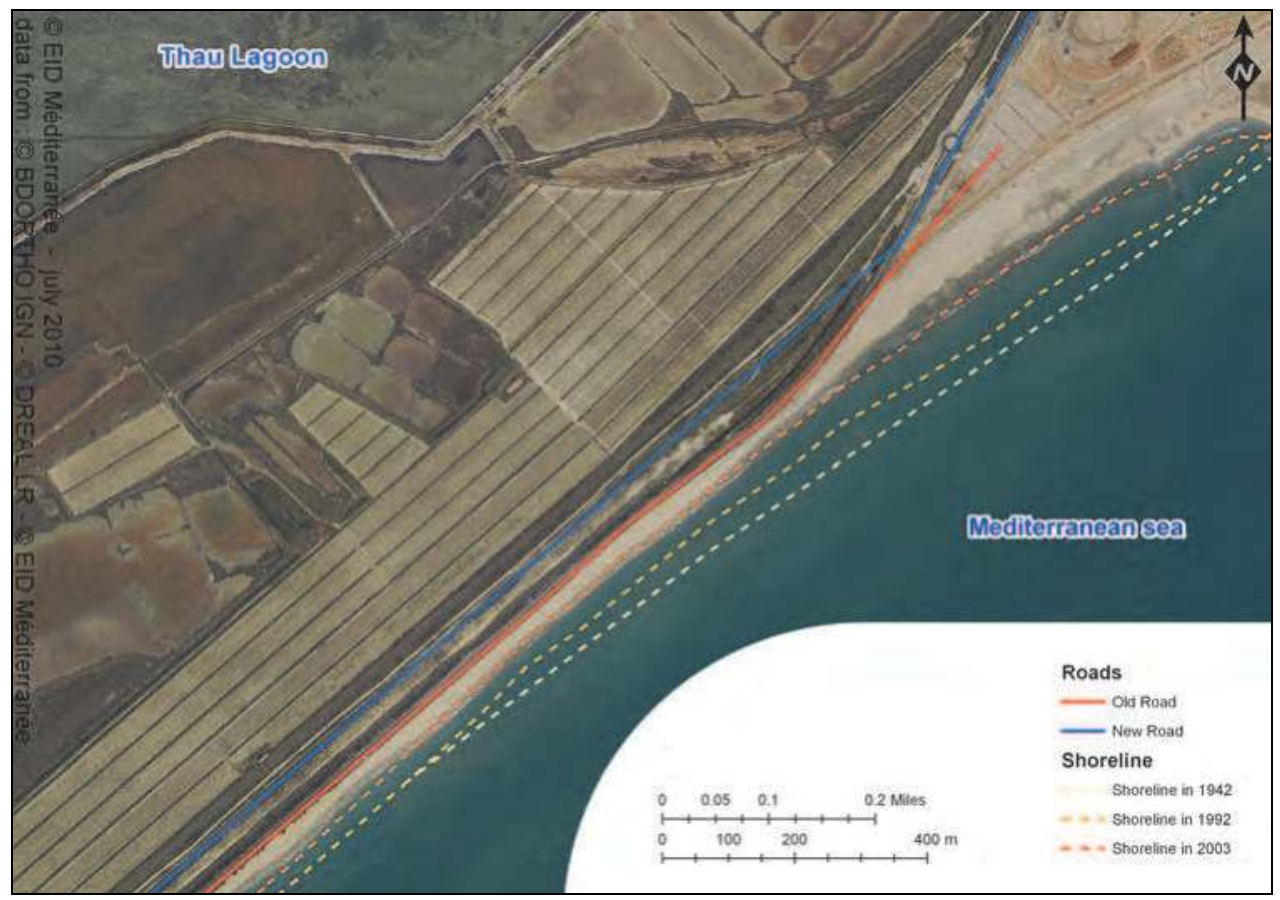

Fig. 11. Shoreline erosion between 1942 and 2003

Moreover the sand strip is separated to adjacent coasts by almost impervious frontiers to sediment transit. As a result the sand strip receives practically no sand supply from nearby sectors (no river mouth in this part). This morphodinamical context is aggravated by Human use of the space. The sand strip is indeed strongly damaged because the fore-dune is truncated on its length by coastal road between Sète and Marseillan. This road, built in the 1920 's on the semi-fixed dune massifs, fixes the littoral system. But a beach and its fore-dune constitute an interdependent system which behaviour is characterized by seasonal variations (Paskoff, 1998). With the construction of the road on the semi-fixed dune massifs, systems lose a part of its natural mobility. During sea storms, the sediment stock constituted 
by the dune isn't mobilized anymore by the wave's effect. The result is a increased erosion on the sand strip. Furthermore, the road presence induces lawless parking practically on the beach of thousands of vehicles and camping-car, which emphasizes the very damaged vision of the site.

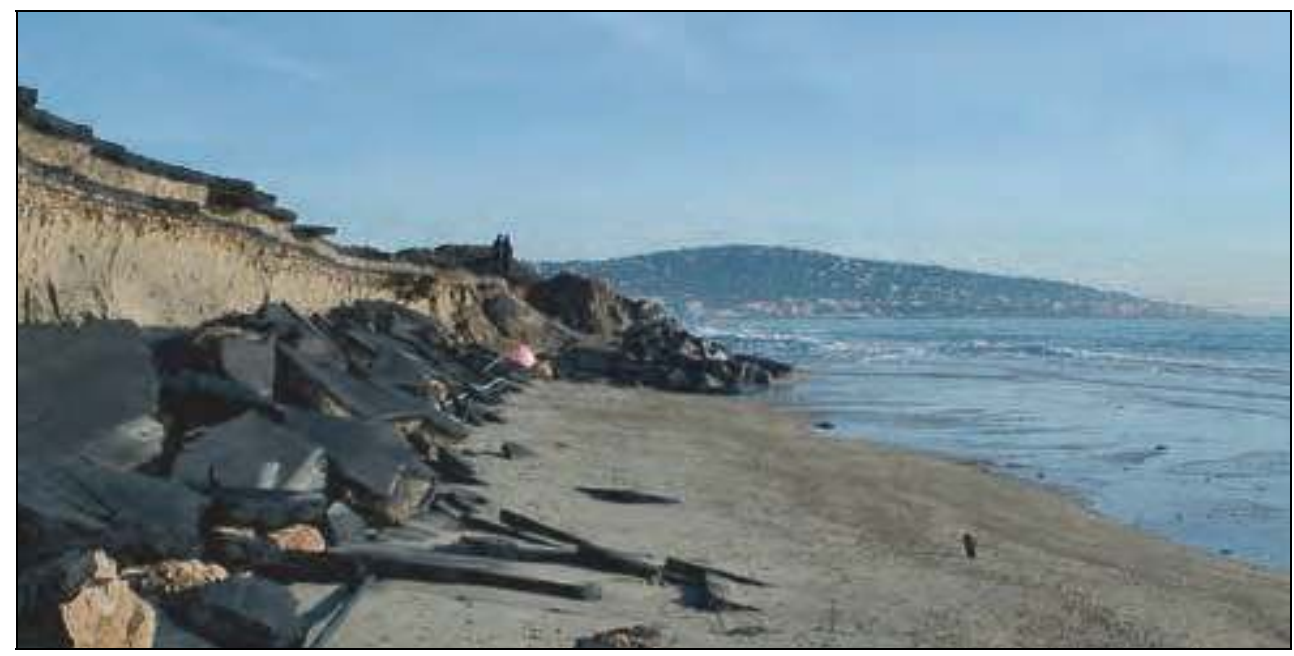

Fig. 12. Frequent destruction of coastal road due to storms (source DREAL LR)

\subsection{Coastal management of Sète-Marseillan sand strip}

To face up to the ineluctable sand strip erosion, and to protect the road to storm wave action, many protective structures have been gradually setting up during last decades. Step by step, the road has been almost completely protected on its length by a line of rip-rap. Two sets of groynes have been constructed at four kilometres on the South-East of SaintClair Mont and a set of breakwaters at Sète, where the road was the most close to the sea. But the problem hasn't been solved by these constructions. In contrary, the line of rip-rap has accelerated the recession of the beach and the groynes and breakwaters have moved and aggravated the erosion in the downdrift sectors.

In fact, used hard protection methods were a failure, in particular to face the catastrophic recession of the Ouest part of the Corniche beach. Coastal services and the Sète municipality have decided to shift backward the road in this sector on a length of 1 kilometre. The operation, achieved in 1990, enabled to solve recurring destruction problems of the road. But it didn't solve the problem of the recession of the beach, here and on the rest of the sand strip. That's why different stakeholders embarked at the beginning of the 90 's in the research of a sustainable solution to the problem of coastal erosion on the whole length of coastal line.

Between 2000 and 2002 a study had been realised about the erosion in the sediment cell from Sète to Marseillan. The scenario of creation that had been selected consisted in the setting up of 11 breakwaters and an associated beach nourishment of $100000 \mathrm{~m} 3$.

Those propositions have been rejected because an economical and environmental realization was emerging in the mind of decision-makers indorsed by technical services, the Interministerial Coastal Development Mission, and the Coastal and Navigation Service. They 
considered that proposed heavy techniques would need the protection of the whole 11 kilometres of the sand strip by these constructions. To avoid that, a project more innovative and more ambitious has started.

The new project started in October 2007 and should last 4 years. At Sète in 2010, 50\% of the project were realised. It is planned the shifting of the road, the parking reogarnization, a new traffic plan, a cycle track and a beach wider with a dune re-created enough far from the shoreline to not be subjected to the storm wave action. The old road and all the others networks have been destroyed and replaced by an equivalent one's less wide with speed constraint, located more into the sand strip. It corresponds to a medium remoteness from the sea of 40 meters into the Easten part and several hundred of meters in its Western part (cf. figure 11). Road shifting has been limited by clear space of the railroad. Frequenting management has been comprehended with an organization with three parking areas along the sand strip, for a total capacity of 2290 places, and the impossibility to park vehicles along the new road. By this project three types of beaches will be defined: wild, semi-natural and urban, relative to their facilities level and their accessibility. Damaged natural areas will be requalified and the conditions to continue wine-growing will be maintained.

In this way, the Sète-Marseillan sand strip's project is a case of managed realignment. The shifting of the road will permit to remove the space necessary to beach and coastal dune restoration. In this case, managed realignment isn't a coastal abandonment but rather the definition more behind of a new shore line, easier to manage.

Considering the scale of this project, with a cost of 55 millions of Euros (Thau Agglomération, 2009) it is a costly project. It corresponds to an investment of 5000 euros.m-1 of coastal line. In comparison, the scenario with the building of hard structures of 2002 would have cost only 2200 euros. $\mathrm{m}^{-1}$ of coastal line. Economically each land development project is considered as an investment for the decision makers. To be validated, this project must be as beneficial as possible for people's interest. In the case of Sète-Marseillan land strip, this project seems to be profitable for many reasons. In a first place it was tried to make sustainable choices for this project. The restoration of sediment dynamic cell will permit to reduce reparation works due to storm wave action. Before this project, the average cost next a storm for the Thau lagoon collectivity was 150000 Euros. With the trend of more extreme events due to climate change, Sète-Marseillan land strip shifting seems profitable. Moreover these storms could damage afterwards others economic stakes like the bottlefilling firm and the camping. It is even more profitable because interests are not only economic but related to road users' security, the rescue mobility and the end of salubrity problems too. In a second place this project is profitable through its resulting effects. It is supposed that with the quality of the landscape and the infrastructures, tourist activity will increase. Besides maintaining this road is a wide economic interest for the Sete and Marseillan towns.

Thus despite its high cost this project seems included in a long term dimension. Its investment was decided to last at least 30 years. With this temporal dimension this project is profitable by the diversity of induced elements too.

As a project of M.R., this project has required several techniques (cf. figure 13) quite recent for some of them and it was a real opportunity for implementing soft-protections technologies. First it has been necessary to restore the coastal dune on 7 kilometres. The objective was to obtain a dune with a slope on the sea side of $23^{\circ}$, a slope of $13^{\circ}$ on the sand strip side and a dune of 14 meters width. A nourishment of 600000 cubic meters has been necessary for the dune and the beach. Then the sand is supplied naturally by the wind. The use of woody fences, an ecological engineering technique, permits to reduce the wind speed 
and to maintain the sand on the dune. On the coastal dune, six woody fences lines were set up to reconstitute the dune. Another line has been built on sea side to put under protection the coastal dune.

In relation with dune restoration, the revegetation was implemented. Vegetation reduces wind erosion and permits to consolidate the dune. 4 kilometres of dunes have been punctually restored with plantings of marasm grass (Ammophila arenaria). To enhace plants survival rate, this technique was combined with the use of geotextiles. Within the framework of biodiversity restoration, a plant nursery of dune plants (Ammophila arenaria, Anthemis maritima, Elymus farctus) was realised. These specific dunes plants will be reintroduced. In the same way, as compensatory measure within the Natura 2000 context, some protected plants that would be damaged during the work have been removed. That is the case of "Jupiter's beard" (Anthyllis barba-jovis). The project damaging habitats too, for each temporary pond destroyed by work, five will be created.

Then the work includes the displacement of the road, to move this stake away of coastal hazards but to let enough places for pre-cited techniques.

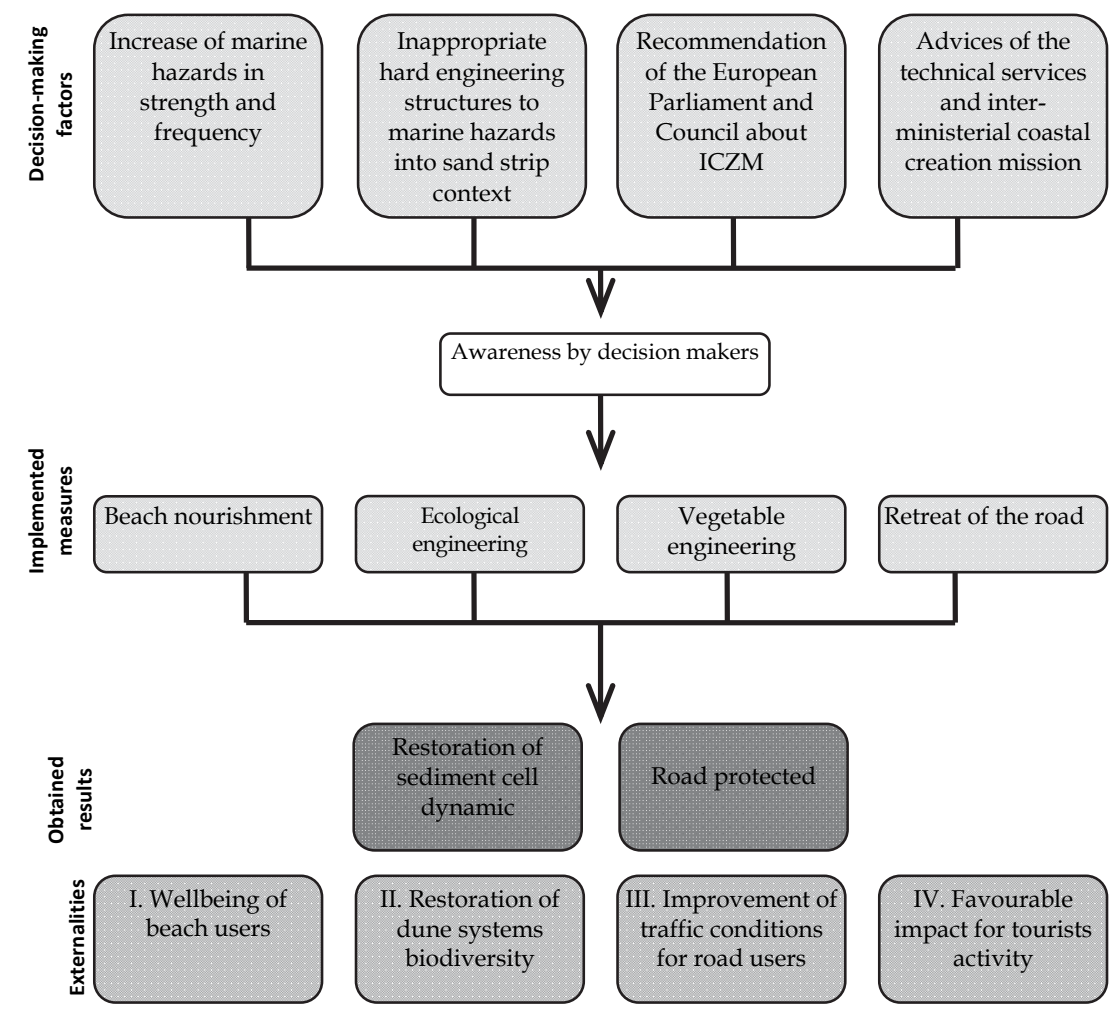

Fig. 13. The framework of Sète-Marseillan sand strip project 


\subsection{Caracteristics of coastal management induced by M.R.}

By these measures, it will permit the restoration of the sediment cell dynamic, and a longterm protection of the road. This project brings about four externalities too. The main externality is the wellbeing of beach users. After the end of the work, the landscape will be nicer and the beach wider. Linked to this externality, that project will have a favourable impact for tourists' activity, which is the fourth externality. Thus by these two externalities, this project will have a social and an economic interests. The second externality is the restoration of dune systems biodiversity. With more space and a better protection for biodiversity, this project presents an environmental interest. Finally, the project will improve the traffic and safety conditions for road users, which is a social and logistical interest.

\section{Discussion}

As the Petite Camargue case demonstrates it, protecting the coast everywhere by fixing the shoreline is not realistic in a technical point of view and in a financial one. It is maybe preferable in current context of climate changes to keep a space of evolution to shoreline and natural functioning. The current realization of problems related to climate changes seems to offer today a hope. This study indicates also that today, it seems necessary to anticipate, and to accept a retreat where the stakes are not directly under sea attacks, and activities reconversion.

This solution is possible only if all the concerned stakeholders share the same diagnosis, and accept to talk without a priori of solutions to give. So, technicians have to be clear and good at explaining, in order to permit everyone to appropriate themselves this complex knowledge. Moreover, landowners and users have to accept an evolution of coastal uses. Nevertheless, private interests in short or mid-term prevail often over the collective interests in long-term.

Concerning the Sète-Marseillan sand strip case, the objectives of this M.R. project were essentially related to logistical and economic aspects. The road was frequently partly destroyed and the construction of hard engineering structures was expensive and not sustainable. These factors have been the determinants of the project and they have permitted the improvement of others points that were corresponding to others aspects. Thus related to the different externalities, social and environmental aspects have been improved. These aspects belong to the scheme but they didn't have the same importance into the decision making process. The environmental aspect could have been more favored. In the French law, Barnier's law relative to environmental protection strengthening defines the precautionary principle. The exposition of this principle is that "Certainty absence, given our current scientific and technival knowledge, mustn't delay the use of measures preventing a risk of large and irreversible damages to the environment" (French Government, 1995). Given the high environmental richness, environmental efforts could have been stronger. This analysis of the importance of each aspect is interesting related to the other European vision of M.R. and their determinants.

Nevertheless this remark must be moderated. Indeed in several points this scheme is innovative. On one hand it is one of the first M.R. implementation in France. In that frame, this is one of the first projects in France mobilizing this kind of ecological and vegetable engineering techniques at a several kilometres scale. The space project has been categorized relatively to its function too: wild, semi-natural and urban. A particular point of M.R. 
projects is to succeed into the structure of the actions to realize between natural and urban areas. On another hand, this plan was integrating into its first phase in 2003 public consultation. During public presentations and meeting, people have been really interested by the scheme and conscious of the urgency in view of coastal erosion (Observatoire du Littoral). By this participative process, social component was an integral part of the project from its beginning. Besides this realization is in line with European orientations of coastal management. Sète-Marseillan sand strip project is an example, in terms of method and contents, of the European Parliament and Council recommendation of the 30 $0^{\text {th }}$ may 2002 relative to the implementation of Integrated Coastal Zone Management. It is linked to erosion management works at European scale into Beachmed Interreg III C and Messina Interreg III C programs. In Beachmed Interreg III C, the objective is to design new coastal management methods taking into account natural and socio-economic aspects. Messina Interreg III $\mathrm{C}$ is intended to mutualize local management knowledge about erosion phenomenon.

\section{Conclusion}

There are many special features of M.R.. One of these features is to move back the economic assets on the coast to the hinterland. It is also to create a new defence line behind the beach and facing the sea to restore natural areas and to create a buffer between the sea and the economic assets. Another feature is to avoid the construction of new economic assets in areas where they would be vulnerable. This diversity of features implies a deepening of the communication among coastal managers. The possible project in Petit Camargue would create a new defence line behind the beach, allowing the restoration of natural areas and a buffer between the sea and the economic assets. It would be a real opportunity for the development of a cost benefit approach.

In the same way, the shift of the Sète-Marseillan coastal sandy beach is a managed realignment case where a major road was moved and a small part of a camping site was destroyed. As a result, this project will limit coastal risks, and also, through a public communication campaign, be a catalyst to increase tourist activity. However, around the same time as this M.R. project, there was a housing development project in the Eastern part of the Sète-Marseillan lido which, unfortunately, ignored the risk of coastal erosion and submersion. Some local surveys show that a majority of people don't have any recollection of storms that have caused considerable damages in this area. This lack of knowledge, together with a pressure from the public and developers to provide more housing, enables such a development to continue.

\section{References}

ABPmer; The Online Managed Realignment Guide - Beltringharder Koog; URL: http://www.abpmer.net/omreg/index.php?option=com_content\&task=view\&id= 64\&Itemid=63; consulted in July 2010.

Allard, P., Picon, B., Claeys-Mekdade, C., Killian S., Astier L., Malangou, S., (2005) - Gestion du risque inondation et changement social dans le delta du Rhône : Les " catastrophes " de 1856 et 1993-1994. Rapport DESMID, CNRS UMR 6012 ESPACE EA 3293 Université de la Méditerranée. 148 pp. 
Bawedin, V. (2009). La gestion intégrée des zones côtières (GIZC) confrontée aux dynamiques territoriales dans le bassin d'Arcachon et sur la côte picarde, thèse de doctorat sous la direction de Alain Miossec, Université de Nantes, 532 pages

Bethemont J., (2000) - Actes du colloque « Le changement climatique et les espaces côtiers » Chapitre 15 : Table ronde : le delta du Rhône et l'élévation du niveau de la mer, $\mathrm{p}$ 82 à 86 , Arles.

Bourrelier, P.H. (1997). La prévention des risques naturels, rapport de l'instance d'évaluation. Paris, La Documentation Française.

Canadian Government; Impacts et adaptation liés aux changements climatiques : perspective canadienne, (2004).

Chambre de Commerce et d'Industrie de Montpellier; Le poids économique des plagistes Enquêtes auprès des plages privées de la Grande Motte et de Carnon; february $2010 ; 9 p$.

CETE / SMNLR, (2002) - Etude sur l'évolution du littoral sableux du golfe du Lion (de 1942 à 1998).

Coastal Concern Action Group ; High altitude aerial photographs courtesy of Environment Agency ; URL: http://www.happisburgh.org.uk/gallery/highalt ; consulted in July 2010.

Conservatoire de l'espace littoral et des rivages lacustres, (1998) - Plan de gestion des domaines de Terre Neuve et de la Capelude, $172 \mathrm{pp}$.

Corre J-J., (1971) - Etude d'un massif dunaire le long du littoral méditerranéen : structure et dynamisme du milieu et de la végétation. Colloques Phytosociologiques, I la végétation des dunes maritimes, p 201 à 225. Paris

Corre J-J., (1984) - La végétation littorale des environs de Montpellier, 34 pp. Institut de botanique-Université Montpellier II.

Department for Environment Food and Rural Affairs; Making space for water, Taking forward a new Government strategy for flood and coastal erosion risk management in England; First Government response to the autumn 2004 Making space for water consultation exercise, March 2005, 47p.

Dickie, I.; Internal communication ; June 2010.

Durand, P.; L'évolution des plages de l'ouest du golfe du Lion au 20ème siècle. Cinématique du trait de côte, dynamique sédimentaire et analyse prévisionnelle. PhD Thesis, Lumière Lyon II University, 1999, 2 vol., 461p.

Entente Interdépartementale pour la Démoustication ; Rapport d'étude phase 1 : Etat de l'art et diagnostic sur les phénomènes d'érosion et de submersion marine ; 2010, 100p.

European Commission ; Livre vert, (2007).

European Commission; European Union action to struggle against climate change, climate change adaptation, 2008, 22p.

European Commission; Part IV - A guide to coastal erosion management practices in Europe: Lessons learned; 2004, 27p.

European Commission (2004). EUROSION Living with coastal erosion in Europe: Sediment and space for sustainability, 164p.

Favennec J., Larroque B., (2004), ONF - Etude de l'incidence de la création d'un cordon de dune-digue sur le site de Terre Neuve, 30 pp. 
French government; LOI no 95-101 du 2 février 1995 relative au renforcement de la protection de l'environnement; Official french government publication n²9, 3rd february $1995 ; 43 \mathrm{p}$.

Goeldner-Gianella, L., (2007) - Perceptions and attitudes towards de-polderisation in Europe : A comparison of five opinion surveys in France and in the UK; Journal of Coastal Research, 23/5, pp. 1218-1230.

Heurtefeux H., Grosset S., Valantin P.-Y., (2007) - Une approche alternative de la gestion des risques côtiers, l'exemple de la petite Camargue, $12 \mathrm{p}$.

Heurtefeux H., Richard P., (2005) - Vingt ans de protection des dunes littorales par des techniques douces : bilan et perspectives à travers quelques exemples en Méditerranée française. In Milieux littoraux, nouvelles perspectives d'étude. Ed. l'Harmattan, Paris, p143 à 166.

Hugo, V. (1846). Discours à la chambre des pairs sur la consolidation et la défense du littoral.

Institut des Aménagements Régionaux et de l'Environnement, (1994) - Domaine de TerreNeuve Commune du Grau-du-Roi Gard: Expertise écologique, Inventaire du patrimoine naturel. 12pp.

Intergovernmental Panel on Climate Change; Contribution of working groups I, II and III to the fourth assessment; 2007, 104p.

Klein, RJT, Nicholls RJ, Ragoonadeu S, Capobianco M, Aston J, Buckley EN; "Technological options for adaptation to climate in coastal zones" Journal of Coastal Research; 2001; 17(3):531-543.

Ledoux, L. ; Actes de l'atelier « Chaud froid sur le littoral » ; 2005.

Ledoux L, Cornell S, O'Riordan T, Harvey R, Banyard L, (2003) - Managed realignment:towards sustainable flood and coastal management. CSERGE working paper, forthcoming

Léger, F. ; Actes de l'atelier « Chaud froid sur le littoral » ; 2005.

Mauger J., (2006) - Quand les enjeux le permettent, organiser le déplacement des équipements, expropriation-indemnisation : Criel-sur-Mer, « de la défense contre la mer à la gestion durable du système côtier ». A.N.E.L., Torreilles.

Moulis D., (2006) - L'évolution des pratiques de lutte contre l'érosion en LanguedocRoussillon. Actes du colloque des journées d'étude " de la défense contre la mer à la gestion durable du système côtier ». A.N.E.L., Torreilles.

Observatoire du littoral ; De la recommandation européenne sur la GIZC à sa mise en œuvre locale : protection et aménagement durable du sand strip de Sète à Marseillan ; URL : http://www.littoral.ifen.fr/Sand strip-de-Sete-a-Marseillan.168.0.html; consulted in July 2010

Observatoire National sur les Effets du Réchauffement Climatique; Stratégie nationale d'adaptation au réchauffement climatique; La documentation française, 2007, 97p.

Paskoff, R. ; Les littoraux. Impact des aménagements sur leur évolution ; (1998), 3rd edition in A. Colin, 257p.

Rupp, S., and R. J. Nicholls (2002): Managed Realignment of Coastal Flood Defences: A Comparison between England and Germany. In: B. v. Kappel (ed.), Prepared for Proceedings of "Dealing with Flood Risk" An interdisciplinary seminar of the regional implications of modern flood management. Middlesex University, Enfield, $1-11 \mathrm{p}$. 
Sabatier, F., 2001 - Fonctionnement et dynamiques morpho-sédimentaires du littoral du delta du Rhône, Thèse, Université Aix-Marseille III, 272 p.

San Fransisco Planning + Urban Research Association; Strategies for managing sea level rise; URL: $\quad$ http://www.spur.org/publications/library/report/strategiesfor managingsealevel rise_110109; consulted in July 2010.

Thau agglomération; Dossier de presse (2009) - Thau agglomération s'engage dans la protection de ses lidos; April 2009; 26p.

Trevi, A.; Nomadic hotels and lighthouses; Pruned, on landscape architecture and related fields; URL: http:// pruned.blogspot.com, October 2008. 


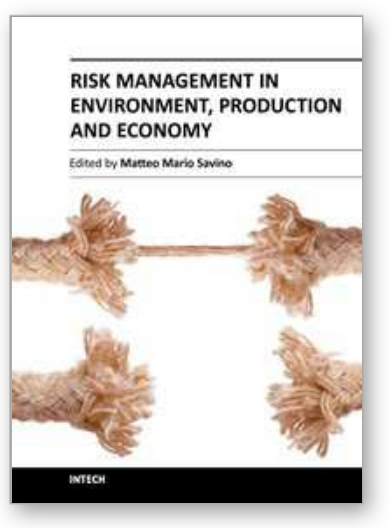

\author{
Risk Management in Environment, Production and Economy \\ Edited by Dr. Matteo Savino
}

ISBN 978-953-307-313-2

Hard cover, 214 pages

Publisher InTech

Published online 12, September, 2011

Published in print edition September, 2011

The term "risk" is very often associated with negative meanings. However, in most cases, many opportunities can present themselves to deal with the events and to develop new solutions which can convert a possible danger to an unforeseen, positive event. This book is a structured collection of papers dealing with the subject and stressing the importance of a relevant issue such as risk management. The aim is to present the problem in various fields of application of risk management theories, highlighting the approaches which can be found in literature.

\title{
How to reference
}

In order to correctly reference this scholarly work, feel free to copy and paste the following:

Hugues Heurtefeux, Paul Sauboua, Provence Lanzellotti and Amandine Bichot (2011). Coastal Risk Management Modes: The Managed Realignment as a Risk Conception More Integrated, Risk Management in Environment, Production and Economy, Dr. Matteo Savino (Ed.), ISBN: 978-953-307-313-2, InTech, Available from: http://www.intechopen.com/books/risk-management-in-environment-production-and-economy/coastalrisk-management-modes-the-managed-realignment-as-a-risk-conception-more-integrated

\section{INTECH}

open science | open minds

\section{InTech Europe}

University Campus STeP Ri Slavka Krautzeka 83/A 51000 Rijeka, Croatia Phone: +385 (51) 770447

Fax: +385 (51) 686166 www.intechopen.com

\section{InTech China}

Unit 405, Office Block, Hotel Equatorial Shanghai No.65, Yan An Road (West), Shanghai, 200040, China 中国上海市延安西路65号上海国际贵都大饭店办公楼 405 单元 Phone: +86-21-62489820

Fax: $+86-21-62489821$ 
(C) 2011 The Author(s). Licensee IntechOpen. This chapter is distributed under the terms of the Creative Commons Attribution-NonCommercialShareAlike-3.0 License, which permits use, distribution and reproduction for non-commercial purposes, provided the original is properly cited and derivative works building on this content are distributed under the same license. 